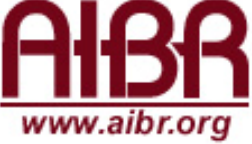

\section{INTERVIEW WITH EDITH TURNER}

\section{George Mentore}

University of Virginia

Editor: Lydia Rodríguez

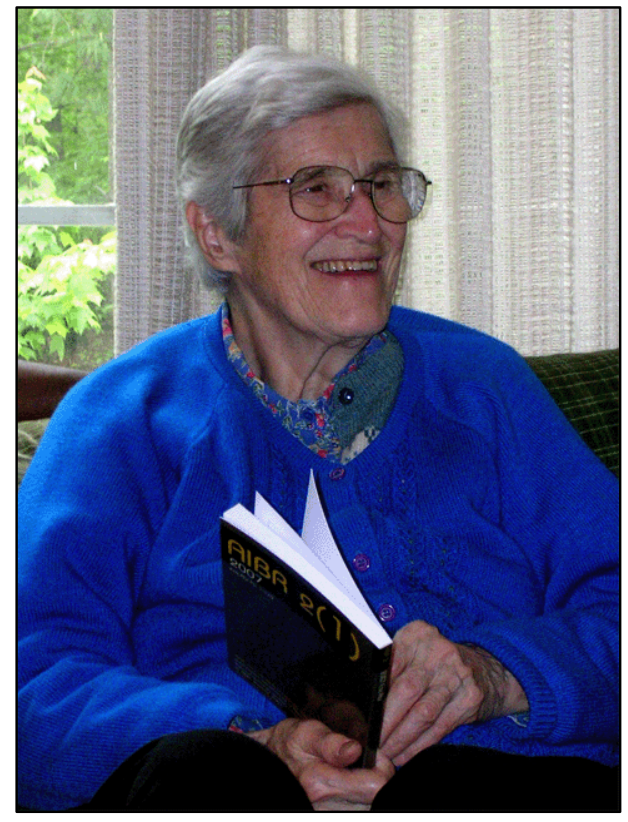

Edith Turner is one of the legends of anthropology of our times. The anthropologist who enters her home can't help feeling a mixture of awe, respect, and excitement contemplating the Ndembu masks that cover the walls. There are also very different artifacts from other places of the world, like Alaska. These are silent witnesses of the more than 60 years of research that Edith Turner has conducted, formerly in collaboration with Victor Turner, and later by herself.

Edith Turner has devoted her life to the study of ritual and symbolism. During her more than 60 years of research she has worked in places as different as Zambia, Alaska, and Ireland. She considers herself a practitioner of humanistic anthropology and the anthropology of experience. She has published several books, dozens of articles, and she is the current Editor of the journal Anthropology and Humanism. At her 87 years she continues teaching her courses on Fieldwork and Ethnography, The Anthropology of Religion, and Shamanism and Healing, among others, at the University of Virginia, being one of the most beloved and respected teachers both by her students and colleagues.

George Mentore is a Professor of Anthropology at the same department and a good friend of Edith Turner. He has worked for more than twenty years in the Caribbean and Lowland Southamerica. It was an honor for AIBR having the chance of asking him to conduct this interview. We have done some minor edits to the original transcript of the interview but in general we have decided to keep it as close to the original as possible, so that our readers could enjoy the informality and cheerfulness of the original conversation between these two great anthropologists.

Edie, tell us about your beginnings in anthropology. While you were raising your sons, in the fifties, you and Victor were being "raised" in anthropology by Daryll Forde, Meyer Fortes, and Edmund Leach, among others. What do you remember about this period and which of these anthropologists has had more influence in your vision of anthropology?

Daryll Forde was the head of the Department of Social Anthropology at University College London at that time. Vic Turner and I learned a lot from his interest in the Yoruba agricultural 
system (I mention myself because, although I was rarely able to study anthropology in the official system, Vic taught me everything he learned). Daryll Forde was a kind of early honest Marxist, a very practical person. He would show how the means of production brought about the particular kind of Yoruba social structure, and you could see the common sense of this. He taught the anthropology we know and teach now, based on actual finds in the field. Those who teach this remind me of good pastors in a church, teaching the gospel as it is. The teaching of Meyer Fortes was very important too. Vic had great respect for Meyer Fortes, because of the depth and brilliance of his fieldwork. Gordon Childe was the archaeology star of the time, so from time to time he would come in the classroom, bearing a new skull he had just discovered. These were building up anthropology in the proper kind of David Schneiderian way, accumulating good, commonly understood theoretical material about the human being, always a basis for more. John Middleton, the Africanist, was a student at the time. And there was another, who worked in one of the Caribbean islands, Michael Smith. This was how Vic became interested in performance studies. Mike Smith was studying the performance aspects of Jamaican politics and government, headed by Bustamante, a kind of Ahmedinajad. In the background was Evans-Pritchard, whom we met at conferences. We both learned much from his ethnography, Witchcraft, Oracles and Magic Among the Azande, The Nuer.

\section{That was the time when you met Max Gluckman?}

Yes, we did. Vic met with Max Gluckman, just about when Vic was finishing his courses in London, and Max kind of spotted him. Vic hadn't worked with Max, he had only met him. Max was a Marxist, and the big ideas that Max was interested in, like the dialectic and change, these other anthropologists were not, except for Mike Smith. From Smith's studies in the Caribbean he was very interested in change and the Hegelian dialectic. We saw the idea of the inevitability of change embedded in Marxism too. So when Vic came to study rites of passage, he thought about the dialectic, and he thought about change in the context of a new station of life. Vic's work focused on the middle stage of rites of passage. However, he saw it as very different in nature, not like the middle stage of the dialectic, antithesis, but at that time, as what I think was something undecipherable by anthropologists, even Van Gennep. Max himself wrote an article on rites of passage in Van Gennep, and I think only once did he ever refer to that middle period, the liminal. When we came back from the field Max Gluckman was giving his department the concept-and that was very good-of process, rather than structure, so the living dynamics, as he would call it, of human action were what we were looking at, rather than at structures of society. 
I'm curious about the movement from London to Manchester. Was it Max that moved?

Yes, that was Max. He was in Oxford at first, with Evans-Pritchard. Max had a good respect for Evans-Pritchard too. And there had been other people at Oxford, like Malinowski. Max received this offer to head the department at Manchester. He had already done his fieldwork in Zululand, Witwatersland, Africa, but he was back and forth between Africa and England. So Max brought Vic with him to Manchester, and we were happy with the Manchester system. However, we had three children to support on what Vic had, equivalent to a teaching assistantship. It was shortly after World War II, and we were still on rations. There were plenty of rich people around who had made money profiteering on World War II, and people felt a lot of envy. We became communists for one year.

It's interesting, how did you get into America with that?

By doing something quite complicated. Technically we had been in the party.

Well, I had to do something similar for the British Post Office, I had to swear I was never a member of the English Communist Party...

Were you?

No, I wasn't...

Oh well, I was, I had a card...

Wow, Edie, that's quite a thing!

I've confessed it!

Let's move on to Africa. How did you feel when you first knew that you were going to do fieldwork in Africa?

Just marvelous! I don't know why. I used to read adventure books when I was about eight years old. I started reading sea stories of people going to the Pacific in sailing boats, by Henty... And all I wanted was this. So when I arrived in Africa, it was just great! I was awfully greedy for excitement and for everything. It was a very fortunate era to live in, to live when 
we did. And there were some marvelous true accounts of people, the great English sort of adventurous type, like Daisy Bates, in the middle of the desert interior of Australia, wearing her tall boots and carrying her black umbrella, studying the aborigines. We've always been proud of these crazy people that do all these crazy things, we knew they were crazy and we loved it! Actually, more than craziness, it was just the love for adventure, and the curiosity of finding out for yourself, seeing with your own eyes what these other people and these different worlds were really like.

My father was a clergyman of the Anglican Church as well as a medical physician and surgeon, two careers in one. My mother was a trained teacher, and a Christian missionary. They had inculcated the Bible into us as something that was absolutely true. Nothing spiritual after when the Bible had been written was to be believed, because that was the end of the Revelation, it was literally what Revelation is about, and that was it. So I had to be a good Christian, and I had to be a good scientific minded person, and I was not allowed to think otherwise; there was a lot of thought control. That's how I was brought up. By contrast, being in Africa was absolute pure joy and bliss, where in their religion they had a tremendous open door to all the spiritual things, and you could learn about people, and you liked people, and people liked you.

\section{Tell us about your informants, Manyosa, Musona, and Muchona, possibly the most famous informant of the history of anthropology, the informant that every anthropologist hopes to find in the field.}

My main informant was Manyosa, and Vic worked with Muchona, and also Musona, who hired himself as cook and everything else. And I didn't mind if he wanted to do it. That allowed me to see the girls' initiations ${ }^{1}$, and I was also doing surveys and so on. When we first started out, it was Musona who first befriended Vic, so we were with Musona's people, and Musona spoke English. It was immensely useful to have him around. When we went to the main boy's initiation ritual (Mukanda²), we had Musona. Muchona gave us the exegesis afterwards. Muchona had previously worked with Charles White, and an earlier anthropologist, so he knew the sort of information that anthropologists wanted. He didn't speak much English, but by working with these people I think from that contact he had developed himself as within his own culture. He was a small man, very articulate and spontaneous. I don't know what it would be like if we hadn't had that major mentor. Muchona

\footnotetext{
${ }^{1}$ Nkang'a ritual, or girls' "ripening ceremony", described in detail by Edith Turner in: "Zambia's Kankanga's Ritual, The Changing Life of Ritual," and in Victor Turner's The Drums of Affliction.

2 Described in detail in Victor Turner's "Mukanda: Rites of Circumcision" in The Forest of Symbols and in Edith Turner's The Spirit and the Drum. 
was like Yoda in Star Wars, a black African cheerful kind of Yoda. He was just wise. He reminded me of Ositola, a Yoruba scholar of the Yoruba. Ositola was brilliant and right, although certain African philosophers are not as interested because he dares to state the truth of his own kind of spirituality, and they are imitating the West.

\section{I'm curious about the details of everyday life, and how was it like being in the field with your three kids...}

We would get up in the morning, and we would hear the sound "Ho'ti" outside, which means "are you in?" Musona was absolutely convinced that English people had to have an early morning cup of tea, so we had it every day, and then we would have breakfast. We had a big board table, quite a nice carpentry table, which meant we could spread out the long genealogies on it if needed. So we had that space, and we had a box with a locked top, but the only reason we locked it was because dogs were all over the place. I was conscientiously having the kids to myself two or three hours in the morning, teaching them. They were 3,5 and 7 years old, going on 5, 7, and 9. We were happy all that time. As soon as we first arrived, we ordered stacks of books from Foyles, London, children and adventure stories, not much educational material. I made up my own. Every day, when Musona and his wives had prepared our lunch, we would never know where little Fred and Bob and Rene had gone. The little kids were hunting with their pals. We'd hear the older kids singing, "lunch-time--fedi-kum-on--fedi" in a honky-tonk syncopated tune, and here would come the little figures.

\section{Were they learning the local language at the same time?}

Yes they were! Rene reached the stage where she'd go and get Musona, drag him by the hand, and bring him to the house where we were, and he would say in English, "Rene says so and so." She'd forgotten English and she was using Musona as a translator.

\section{So that really helped you and that freed you up to attend many of the ceremonies.}

Yes, exactly. Almost immediately Vic's main field friend recommended one person to look after the kids after the morning class. So I was able to go with the women and attend the rituals that happened almost every week and many other events, because there was always a girl who was being initiated. I would also help the women dig crops, visit the babies, hear ritual life histories, and type. I volunteered to do a lot of typing of Vic's notes, because he was 
handwriting, and we knew that the Rhodes-Livingstone Institute -they were funding usrequired us to send in regularly typed notes.

\section{Was it like this old fashioned British thing where men didn't have to type?}

Vic eventually had to learn... he would type with just one finger of each hand!

\section{When I was in England, it was "domestic science" and typing for the girls, and boys did "good work" and we didn't type....}

That's right, the girls did the typing, I remember that. And I had to teach myself to type.

\section{So basically there's a selection of notes that you and Vic made. Did you take notes in the field when you were there?}

Yes, I did. I took a lot of notes, and typed, and also kept some kind of filing system going, and taught the kids in the morning. I also took pictures. The idea was to take the picture, first establishing in a shot what the actual village and environment was like, so it could be seen as it was. Also, when you are taking photographs in the field, the primary concern, if you can-and I don't see why anybody can't- is for the photographer to get into everything, abandoning oneself in sympathy with them, being the other person, being these people oneself. I was entirely mixed in with them, I was involved in everything they were doing. So when I was in a ritual, and I had the camera, I was sort of being the crowd also, and I would put the camera in between, so there are often crowded figures around, which is exactly how the actual ritual is. And then you get the feeling of everybody around you, and what they're saying, and your part in it, instead of having anything cut and dried. I've noticed that the pictures in Evans-Pritchard's book on The Nuer consist of beautiful poses but not many living pictures.

And then on Thursdays, we would take the day off. Not on Saturdays or Sundays, because that would prevent our major fieldwork, as these were the days when the Africans had their rituals. So we chose another day. We loaded up with sandwiches and went off camping in the bush, scattering the antelopes in the forest, because, as we said, "you kids make so much noise you're scaring the antelopes!" We'd take a ground sheet and we'd find some sticks to hang up the sheet between them and make a little roof, and just sit there and relax from the stormy village life, where there's always something going on, especially when there 
are anthropologists in the place. People would be always coming to visit. Afterwards we'd toil back, tired, and as we were coming near the village we'd hear what you'd usually hear in this village and no other place "Kubobala-bobala-bobala-bobala"--everybody talking at the top of their voices at everybody else. They were probably quarreling about wages, or who's to do the jobs... Other villages were quieter, but we had brought an alien element into the village, they were even smoking Vic's cigarettes, sad to say.

My image is very similar; it is interesting this business of taking the day off. Where I work in Amazonia the villagers also take days off to get away from the village. I mean, Amazonia doesn't have the same amount of population as the Africans, but still there are a lot of people who like to get away, and spend a little time away from the gossip and the intensity of village life...

Yes, it was a marvelous thing to get away from it all. And they say in this motto, rather sadly: "There's trouble in the bush, and there's trouble in the village." If you go in the bush there's trouble, if you go in the village there's trouble, so there's trouble everywhere you go! Trouble in the bush and trouble in the village! You wanna get away from it but it's impossible... For instance, they had wide family relationships, and who gave bush meat to who was very important. If you catch an animal, an antelope, you don't possess it yourself, you have to give it away, in a distinctively customary order to close relatives. So people of the bush will often quarrel about this. I was delighted to find the same thing among the Iñupiat of Alaska, they're hunting meat and game, and they have the same obligations. As for me, I was very lucky in Alaska, I was partly a grandmother in the village, so I received some of the goodies on that account. If I had got any goodies I had to give some of them on to so and so. It's a great way to live. They may quarrel sometimes, but it's a great way to live, absolutely!

Redistribution, yes, it is a nice way to live. So moving on to the US, you arrived in Chicago in 1968; this was a very special year in which many things were happening around the world...

Yes, there was an immense need of improvement of the whole US and world system because of the suffering going on and the neglect of the authorities. It showed up in France first, where the students went on strike in Nanterre University ${ }^{3}$. The strikes developed because of the very bad conditions of the students at the university and the working people. During the protests there was very much communitas, because everybody was talking,

\footnotetext{
${ }^{3}$ Université Paris X-Nanterre
} 
everybody in the universities were having discussions about what were the rights and wrongs of it. Thousands of people were talking who never talked before. Nobody was afraid of talking. There were things inside this moment which you could say were in liminal time, extraordinary things like this enormous procession with everybody going down the street singing. Everybody was happy. There was a huge piano set in the middle of the square and people were playing on it. It was marvelous just to hear the people playing on this piano, anybody could come and play any kind of music. Some of it was good and some of it wasn't. Then they had an assembly in which everybody could speak, and if the person who was speaking was putting a "pseudo-communitas," they would shove him out. Eventually, as a result of this big struggle, the workers were paid more, and the price of milk and the cost of living came down.

At that time, we had just changed jobs. We moved from Cornell where Vic wrote The Ritual Process. We had to sell our house in Ithaca, so we went to Maine for a little vacation, and then we bought our house in Chicago, nearly next door to David Schneider's, about a quarter mile from the University. At the time when we arrived in Chicago we knew that there was a student protest in progress. I remember that I was learning to drive in the city, and I stopped at some shop. A police car drew up and a couple of cops got out. These cops were frightened! They were tense as hell; they were supposed to control all these students, you see, in enormous crowds, and they didn't know if they could hold them. We went to Jackson Park where a huge demonstration was in progress, and we came across Clifford Geertz, who was also in the crowd. He was quoting Yeats, "The best lack all conviction while the worst/Are full of passionate intensity." 4 It was a bitter remark by Cliff Geertz, that all this was the worst that could happen. James Redfield, a Professor on the Committee on Social Thought, who was the son of Robert Redfield, said he was absolutely disgusted with the students! That was very sad...

\section{Who else was at Chicago at that time?}

Fred Eggan, Jean Comaroff, Milton Singer, Terry Turner was in and out. The Anthropology

Department was very strong, in a masculine mood, very structuralist. And of course there was Marshall Sahlins...

\section{He still has a very poisonous pen...}

\footnotetext{
${ }^{4}$ Yeats (1920).
} 
Yes, he does! Marshall Sahlins went to France and grabbed "levistraussianism" as you may call it, or "levistructuralism," the linguistic structuralism of Claude Lévi-Strauss. He went to France as a Marxist, ruddy and sunburnt, in working clothes, and he came back, how to say this?... like a priest, pale, like a white priest in a long white cloak who had seen the light of Lévi-Strauss's brilliant binary discriminations... and he went through that department like that, like a masher of potatoes, and I'll tell you why in a minute. That's the "order" of structuralism... Some of the students would come out their hearings weeping, in trouble because they had neglected to mention his name... Many professors were fighting each other. At the dissertation defenses about six or seven people would be present, and if the student had already taken sides with one or other professor, then the student would get mashed between the two. This is why I call them mashers of potatoes. You had to have very strong nerves, the professors were cruel-except for Jim Fernandez, who was the Joker in the pack, yeah, he was great.

I felt that too, because at $\mathrm{LSE}^{5}$, by the time I was a graduate student in the late seventies, there were a lot of LSE Professors that spent a semester at Chicago, and they came back with this tradition of bleeding presentations, in particular the Friday seminar became notorious as a place for that, for destroying ideas, in these presentations.

Absolutely.

But let me get back a little to Vic's influence. A little while ago I took a look at Michael Taussig's most recent book, What Color is the Sacred?, which came out this year. And he begins with a long quotation from Vic about Ndembu's primary colors, white, black, and red. What do you think makes the work of Victor Turner still so appealing to many modern scholars?

Vic is still so interesting to many anthropologists because he was using absolutely good ethnography. That was the major thing. He wrote down what the people said, and what the circumstances were, and what actually happened, and what people said after that. Vic himself had a scientist father, and I was trained by my father who was also a physician. Vic's father helped John Logie Baird invent television, the scanning process of television without which we wouldn't have any. And the two, Baird and Norman Turner, were sending the first messages ever, by radio, from Baird's house to Vic's father's house. So these two were good

\footnotetext{
${ }^{5}$ London School of Economics
} 
scientists, and so was Vic, Norman's son. This kind of mentality, I think, was obvious in what he writes, but it wasn't in his dissertation, which was mostly under the command of Max Gluckman, who was head of the department at that time, and he had enormous power. Max said Vic shouldn't be looking at ritual, he wouldn't allow him to write a dissertation or a doctorate on it at this stage, and finally he told him he had to write his dissertation on social process--and that was it! Vic chose in the dissertation to follow a number of cases of human conflict and creation of new groups, cases he had collected and sometimes witnessed himself, that is, the crises and changes in a group of people through time; and therefore he managed not to repeat the old structuralism, but to lay out processual anthropology in a way that was only just being discussed at Manchester. The dissertation later became Schism and Continuity.

Vic, as is known, spread his attention to liminality. He focused on Christianity and those truly sacred and particularized times that arise in change or in rites of passage, where there is little of the normal idea of time and space, and the communitas of such rituals seem to be breaking out to the very boundary of humanity. In liminality, in Vic's words, people are "betwixt and between" normality. Liminality is very, very odd. There are often masked figures to be seen, sometime clown figures too. This part of human performance is recognized as the milieu of the sacred and harks back to the far past. Here Vic's ethnography, such as in the ritual of Chihamba ${ }^{6}$, was especially good. I believe Michael Taussig sees this too. As regards shamanism, he sees the energy of indigenous peoples beginning to resist, claiming their shamanism, which has power in the spirit world over and above the power of capitalism. Similarly, concerning this power, Zora Neale Hurston of former years had the same knowledge when she told us of the power of witchcraft available to oppressed people...

It's really interesting you've pinpointed these things, both Zora and Michael and obviously yourself and Vic did this crossover, let's say, from the legitimacies of Western thought to the thought and the experiences of others. And the thing about Michael Taussig's anthropology now is that it's multi-media, multi-dimensional, multidisciplinary, which is what Vic was doing apparently very early on, and I actually think it's probably the secret of his success, and that he appeals to so many different disciplines, and not just to anthropology. While anthropology at the time was trying to be so "scientific" and using the science discourse, narrowing the discourse, Vic was sort of opening it...

\footnotetext{
${ }^{6}$ Cult of affliction in which the patient is affected by an ancestress spirit and by a demigod or nature spirit that impersonates the lightning or thunder 
Yes, he was. And then he went back to theater and performance, with Richard Schechner, and that marvelous sideways figure of eight. The actual events of life, which are so dramatic sometimes, proceed to the unconscious, the lower level of the acts, the thought, and the inner culture of people, and then they emerge as a loop in culture, on stage, movies, novels, books, poetry, and all the rest of it. This emerging model reflects the kind of cultural manner in which people now react, and it goes on around to new events and on to the unconscious, ad infinitum. And it explains much more than a direct cause and effect model created by Western logic, which does not exist in nature. In reality the cause and effect model is always messed up and impure. The scientific method is always trying to isolate some isolated reaction to study, shielded from strange effects, which is "cause." This is supposed to mean that the experiment is repeatable and truly scientific, but the fact remains that it is utterly unnatural! There's no such thing on earth as an absolutely, pure kind of cause and effect situation; we and all things are all mixed up and bound to each other. The scientists are in possession of an imaginary world.

Let's go back to your own personal writing and the history of the writing. Although the manuscript of your first book about Kajima was conceived and first written during the fifties, it was published in 1987 as the famous The Spirit and the Drum, where you talk about healing and ritual in Africa. Only three years later you published your first paper on the Inuit. During the next years, you go back and forth between Africa and Alaska: in 1992 you publish Experiencing Ritual: A New Interpretation of African Healing, and in 1996 - The Hands Feel It: Healing and Spirit Presence Among a Northern Alaskan People.

Yes, that's right.

Tell us a little bit about that transition, I mean, Africa, the Americas... what's the train of thought keeping this together?

Yes, my first book was The Spirit and the Drum, but it wasn't until Vic died and I had gone back to the Ndembu that I finished it and got it published. As you say, my writings done on my own were published after he died. I took a friendly student to help and for company for that return Ndembu trip in 1986. It was easy in a way to write freshly on the Ndembu in Experiencing Ritual because I had plenty of my own information from my new ethnography, although that trip was only for 3 months. The book on Iñupiat healing also came very easily when I came back from the Alaska trip, the second one taken without Vic. But it was 
absolutely valuable, and I could do it my way, you see? And I did. But when I look at it, it's extremely humble, compared to Vic's very serious, incontrovertible anthropology...

But we spoke about that before, and that was precisely the difference; certainly your readers and some other people have spoken about this too, that you were freed up, and liberated from the academy, and produced work that was still anthropological, but not burdened by the scholar tradition or conservatives.

That's right. That academic style had become very much Vic's thing. Vic's fieldnotes were a brave attempt to be a good reporter. His notes on anthropology were faultless anthropology. He didn't write his own feelings in his notes, but he did write poetry. He kept these things completely separated, much as Mary Douglas kept her religion separated from her anthropology. When I look at Vic's work I can see why his work is better than mine, because I don't have the good trustworthy academic style, but I can't help that, and I do not want to change it, because I think that, in the end, if you can't have humanistic writing, what you're getting is what you are aiming to gscientific information that scientists use. And I think that sometime in the future people will really be writing about how another culture alters itself into something else.

This just strikes me as the most important thing you said so far, that the battle between science and art still goes on, and it seems that you are continuing the fight along the humanistic tradition, and won't give up on that. It's important because it sounds like the battle is still worth waging, and the best anthropology seems to be struggling with that issue. And the social science part is suffering from a full development of itself, because it won't engage in the recognition of the humanistic side.

That's right. And people do develop their own styles, and I perceived I wasn't for that style myself, I didn't enjoy it that much. In my writing, I very much enjoy having a sense of being there, which Vic didn't give. His description of the Ihamba ritual in The Drums of Affliction is a blow by blow account of how the doctor took out the tooth ${ }^{7}$ of a sick person. And yet it is quite different from my own description of the same ritual in Experiencing Ritual. Vic's ethnography there was as good as there will ever be, except yours, George, later on in time, and Renato Rosaldo's ethnography on head hunting. When you get real "live" ethnography, it's a marvelous thing, absolutely.

\footnotetext{
${ }^{7}$ The "tooth" here refers to a hunter spirit that embeds itself under the skin of a person, causing strong pain. 
Let me see if I can press this a little bit more. In classical anthropological writing the ethnographer's work is to be the "observing eye" of society, so we could call this something like "visual" ethnography. But in the writings of the people you mentioned, instead of just being able to "see" society, what is sought after is this other capacity of being able to "touch" the scene, so what you are reading becomes so vivid and real that it is almost as if you could touch the scene, and "touching" becomes the metaphor for good anthropology. But there's a current in feminist anthropology that says that what women writers do, and for instance what you do in your work that makes it very different isn't so much the touching, but it's being touched. It's not just a touching, but a recognizing of being touched by the thing that you come in contact with.

Yes, you're right, that's the difference. Being touched, being the ethnic scene or "the other," being the other place, so that it actually works on one. It's not you working to record that. It is working on you! And you're no longer the same person, this is part of your actual living in this world, it's not just notes and stuff on paperback, it's an actual human event that the anthropologist is in! And this is supposed to be very scary, because how can you "lose" yourself, when you should be "observing" it? You begin to burn up, you think it's dangerous, because you "lose your objectivity," and your own unconquerable soul, you have your soul that is yours, and nobody should conquer it at all. And you can't go around letting people influence your "self." All these things are like an enormous kind of erection, almost literally, of the individual, the utterly indivisible and sacred individual. In a sense, one's consciousness of being oneself can be like that, and it can be absolutely fanatical! I don't know how ever people produce children, for instance, if they can't let themselves go and embrace another person. Thank goodness there is sex! Because when you have sex you can let yourself go, you're all permeable. It's the same when you are doing good ethnography and when you are writing about it, you have to let yourself go and become absolutely involved with what you are doing, so that when people read what you are describing they can feel touched as you were touched.

Can you tell us a little bit on what you are currently working on, and how you got to your current project?

Well, I had written a book on healing, and it occurred to me that the healing is done in a certain kind of social atmosphere, and I remembered the course I had given on Vic's concept 
of communitas. So this new book I'm working on is about looking again with an open mind at the concept of communitas, as something that is hard to describe in words, ephemeral and ineffable. It can be said to be the great feeling of all being together, and having extraordinary or terrible times together, a feeling that doesn't necessarily last very long. Of course, others, including Durkheim, have called it "effervescence"-so that it looks like soda pop with artificial sugar in it. Vic took communitas very seriously in The Ritual Process and other books, and he kept saying that nobody had written a book on communitas. One day I was in New Hampshire, with Josh, my grandson, and Rose, my granddaughter who was 23 at the time, and Rene my daughter, and we were chatting about communitas. Rene said: "you know, you could write a book on communitas," and I said, "oh yes, a companion piece to the book on healing, The Communitas." And we were joking away and we thought what it might be like writing this more "relaxed" type of book, looking at all the irrational and marvelous communitas scenes on movies like Chocolat, and Amelie, and The Bridge on the River Kwai...

When Vic was working on the idea, he was building on the idea of liminality, but it sounds like you continue the discussion along the lines of something like "shared joy."

Yes, that's right.

So you're saying that communitas doesn't necessarily need ritual?

That's right, it doesn't necessarily need ritual, but once people get a clue to what's going on, especially if there are great institutional religions in the offing, the religions will all grab onto it. Or maybe it's the other way around, maybe the institutional religions came out of communitas, but of course they also came out of shamanism...

This seems like a good moment to ask this final question: you consider yourself Catholic and at the same time you practice shamanism. How does this mixture of Catholicism and shamanism impact and shape the courses that you teach on shamanism and healing at the University of Virginia?

First, I don't consider myself a "good Catholic" and have all kinds of contrary views. But I come alive at the ritual, and take communion. As well as the other religions, it reaches into the spirit world, as I often say. I'm very glad of it. I'm also very glad to have shamanism. I've 
learned quite a lot about it, and I think it's quite established that in the times before the great religions, there existed this same sense that has produced both shamanism and the religions, so that the positivists' view of life is not what they think it is. When I was a little kid, I had Bible words pushed before me night and day-I don't think there's any verse in the Bible that I have not heard. A lot of it I know by heart. Its inner core is absolutely beautiful and the other half, regrettably, is full of violence. Later on, when I got sickened by aspects of Anglicanism and went to Africa, I was thinking about the nonpolitical, nonviolent stories in the Bible, their style, and the things they were trying to say, the implications and so on. I was thinking about the relationship between these stories and African ritual thought, so that, for instance, understanding and sensing the ancestors' cult became quite easy. The implications at the end of the day were not that different. So this is what I tell the students in my courses: if it is god it's god, and if it's a spirit in your shaman journey, it's a spirit, and if it is Allah, it's Allah, if it's Kami in Japan, it's Kami. There is a spiritual world, it's not that it's different from ours but that the spiritual nature of the world stands out in 3D in its reality. And all these religions are real, every one of them. If any religion considers itself "the only one," that's where such a religion is like this tremendous phallic and fanatical individual that I was talking about before. And this is the very other end of the continuum from where religion really is. This is what we are talking about in the course. We have a list of things like, for example, "have you ever had the sense that there's something you don't know that's trying to tell you something? Have you had the sense that you have seen something before? Have you had the sense that an animal actually does understand you?" These are many kinds of awareness that everybody has experienced a bit of at some point in their lives. So the students know that there is something-they know they can hang on to this something that they do know a little bit about-and work from there, and when the others talk about theirs too and they begin to see they have had comparable experiences, boy, then the fun begins!

\section{So you're saying that what you're trying to teach the students is first to recognize in their own selves that there are experiences that may not have any means of explanation, but they have them, and secondly to get them to recognize that if they can share their experiences, then other people can share their experiences that are also spiritual, and equally true and valid.}

Yes, absolutely! This is not necessarily a matter of "angels" far up on high, this is actually what you have experienced yourself, and it's in nature, and it's your nature to have this. And it's the nature of the universe to have this full range of ways of communicating, we don't know why, all we know is that it's telling us something, and we have to listen to its language, 
because we are not these fanatical units, these phallic individuals. We are completely involved with each other, and it's extraordinary.

\section{REFERENCES}

Evans-Pritchard, Edward. E. (1937). Witchcraft, Oracles and Magic Among the Azande. Oxford: Oxford University Press.

Evans-Pritchard, Edward. E. (1947). The Nuer: a Description of the Modes of Livelihood and Political Institutions of a Nilotic People. Clarendon Press. Oxford.

Taussig, Michael. (2009). What Color is the Sacred? Chicago: The University of Chicago Press.

Turner, Edith. (1987a). The Spirit and the Drum. Tucson: University of Arizona Press.

Turner, Edith. (1987b). "Zambia's Kankanga Dances: The Changing Life of Ritual." In Performing Arts Journal, Vol. 10, No. 3, pp. 57-71. Cambridge: The MIT Press.

Turner, Edith. (1992). Experiencing Ritual: A New Interpretation of African Healing. Philadelphia: University of Pennsylvania Press.

Turner, Edith. (1996). The Hands Feel It: Healing and Spirit Presence Among a Northern Alaskan People. DeKalb: Northern Illinois University Press.

Turner, Victor. (1967). The Forest of Symbols: Aspects of Ndembu ritual. Ithaca: Cornell University Press.

Turner, Victor. (1957). Schism and Continuity in an African Society: a Study of Ndembu Village Life. Manchester: Manchester University Press for Rhodes-Livingston Institute.

Turner, Victor (1968). The Drums of Affliction: A Study of Religious Process Among the Ndembu of Zambia. Oxford: Clarendon Press.

Turner, Victor. (1969). The Ritual Process: Structure and Anti-structure. Ithaca: Cornell University Press.

Yeats, William Butler. (1920). "The Second Coming." In Michael Robartes and the Dancer. Chruchtown, Dundrum, Ireland: The Chuala Press. 